\title{
What Counselors Tell Low-Risk Clients About HIV Test Performance
}

\author{
Roman Prinz $^{*}, 1$, Markus A. Feufel ${ }^{1,2}$, Gerd Gigerenzer ${ }^{1}$ and Odette Wegwarth ${ }^{1}$
}

\author{
'Max Planck Institute for Human Development / Harding Center for Risk Literacy, Berlin, Germany; \\ ${ }^{2}$ The Dean's Office for Educational Affairs, Charité-University of Medicine Berlin, Germany
}

\begin{abstract}
In 1998, Gigerenzer et al. studied how heterosexual men with low-risk behavior were counseled about the accuracy of HIV test results. Most professional counselors conveyed the illusions that false positives do not occur and that a positive HIV test result means that the client is certainly infected. To help improve counseling quality, the authors provided feedback to all counseling centers in Germany. Sixteen years later we assessed whether HIV counseling in Germany has improved by replicating the original study with an expanded sample of 32 randomly selected counseling centers across the country. Since the original research, the positive predictive value (PPV) of HIV testing for a

Roman Prinz low-risk client has improved from about $50 \%$ to $96 \%$. Hence, among every 26 low-risk clients who test positive, we can expect that one is actually not infected. Whereas test performance has improved over the last 16 years, counseling has not. About half of professional counselors communicated the illusion of certainty for sensitivity (15 of 30$)$, specificity (16 of 30 ), and the PPV (18 of 30). Only one of the 30 counsclors could correctly state the PPV. In what follows, we explain how to improve counselors' and clients' understanding of the PPV by representing the information in terms of natural frequencies rather than conditional probabilitics. Doing so has been shown to improve the quality of counseling in different medical settings and may enhance future HIV counseling as well
\end{abstract}

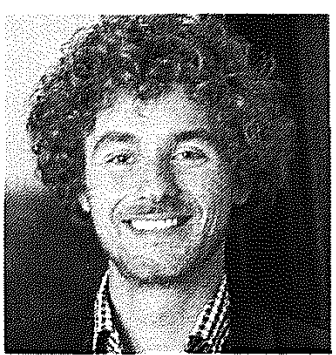

Keywords: HIV/AIDS, HIV counseling, HIV testing, natural frequencies, risk communication, risk literacy, numeracy, transparent information.

\section{INTRODUCTION}

In 1998, Gigerenzer and colleagues investigated in an undercover study how a heterosexual man with low-risk behavior (e.g., monogamous, no intravenous drug abuse) was counseled about the HIV test [1]. Using a convenience sample of 20 health centers, the researchers analyzed what information the 20 counselors communicated during pretest counseling sessions and whether they conveyed it in a way the client could (easily) understand. The majority of counselors communicated illusions of certainty: that false positives do not occur (13 of 19 counselors; one refused to answer the client's questions) or that a positive (reactive) test result most certainly indicates HIV infection (10 of 18 counselors; two refused to answer).

The illusion of certainty refers to the belief that an event, such as a positive test, is absolutely certain although it is not. For instance, in a representative survey, $63 \%$ of 1,000 German citizens over 18 believed that an HIV test result is absolutely certain [2]. Even the World Health Organization wrote in its current fact sheet that "A confirmed positive result from the second test method means that the individual is infected with HIV" [3]. But in fact, the test is not certain $[4,5]$. The statement fosters the illusion of certainty in people's minds. Confusing false-positive results with true positives can have severe consequences, including psychological distress and even suicide $[6,7]$.

\footnotetext{
*Address correspondence to this author at the Max Planck Institute for Human Development, Center for Adaptive Behavior and Cognition, Harding Center for Risk Literacy, Lentzeallee 94, D-14195 Berlin, Germany; Tel: +49(0)30 - 82 406; E-mail: prinz@mpib-berlin.mpg.de
}

Given that most counselors in Gigerenzer et al.'s study provided the illusion of certainty, the researchers forwarded the results to all counseling centers in Germany and also provided guidelines about how to better understand and communicate the performance of HIV tests. Sixteen years after the original study was conducted, we assessed whether counseling has improved.

\subsection{The HIV Test Procedure}

The HIV test procedure typically involves two individual tests. The first test, the ELISA, is an antibody detection test with high sensitivity [8]. If the ELISA is negative, the procedure stops and the client is notified. If the result is positive, the procedure continues with the Western Blot, a virus-specific "confirmatory" test with high specificity [8]. If the Western Blot is also positive, the client will receive notification of positive HIV status. There are variations in this procedure, as it is not standardized. If the first ELISA test is positive, a second ELISA from a different manufacturer may be used and only if both are positive the Western Blot is ordered. Often, the test procedure is repeated on a second blood sample. The inconsistency in the test procedure is also reflected in the counselors' descriptions of the test procedure to the client in our study (see Appendices $A-D)$.

Two possible errors can occur in the HIV test procedure. The first occurs when a client who is infected is notified that he or she is not infected (i.e., HIV-negative). This error is called a false-negative result and the rate of this error (the miss rate) is the complement of the sensitivity of the test procedure. Sensitivity is the probability that the test correctly 
identifies those who are HIV-positive. To illustrate, imagine an HIV test with a sensitivity of $97 \%$. Of 100 people infected with HIV, the test will identify 97 as being positive. It will miss the remaining three infected people, who will be wrongly told that they are HIV-negative (i.e., receive a falsenegative result). The second error occurs when a client who is not infected is notified that he is infected (i.e., is HIVpositive). This error is called a false-positive result and the rate of this error is the complement of the specificity of the test procedure. The specificity is the probability that the test identifies somebody as HIV-negative (i.e., as not infected) if the patient is indeed not infected.

The currently estimated sensitivity of the combined procedure of the two tests on HIV is about 99.7\% [8]. Estimates for the specificity range between $98.5 \%$ and up to $99.9996 \%$ [8-10]. Note that estimates for the sensitivity have been fairly unchanged since 1998, when Gigerenzer et al. undertook their study [1], but those for specificity have improved, depending on the kind of test.

\subsection{Communicating Test Statistics}

What does it mean when a client tests positive? The answer depends on three factors: the prevalence of HIV in the client's risk group, as well as the sensitivity and specificity of the test procedure (i.e., ELISA and Western Blot combined). Consider a prevalence of $0.01 \%$, a sensitivity of $99.7 \%$ and a specificity of $99.9996 \%$. Fig. (1), left side, shows one way to calculate the positive predictive value; hence, the probability that a client is truly infected after receiving a positive test result. The answer is $96 \%$. In other words, among 26 clients who test positive, we expect that 25 are infected and one is not.

As the calculations in Fig. (1) illustrate, deriving this answer is not easy to follow. Sensitivities and specificities are called conditional probabilities and using these to calculate the positive predictive value confuses many experts, as well as most laypeople [11-15]. An effective alternative is to translate conditional probabilities into natural frequencies $[5,16,17]$. Fig. (1), right side, shows how natural frequencies simplify the calculation of the positive predictive value. Note that the four values at the bottom of the right tree are natural frequencies, while the four values at the bcttom of the left trec are conditional

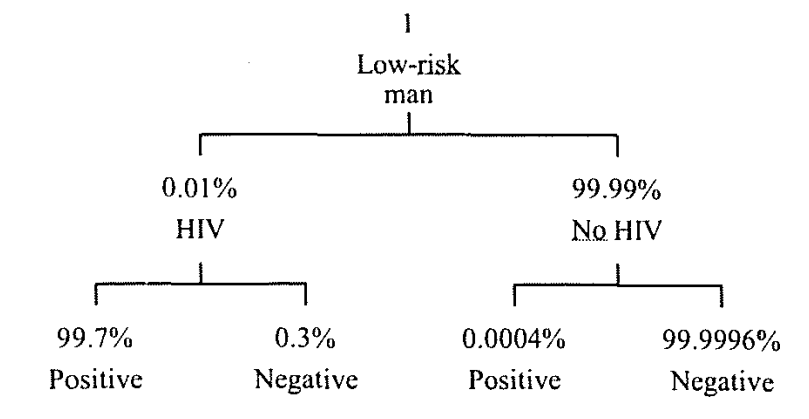

$$
\mathrm{p}(\text { HIV|Test positive })=\frac{0.0001 * 0.997}{0.0001 * 0.997+0.9999 * 0.000004} \mathrm{p}(\text { HIV } \mid \text { Test positive })=\frac{25}{25+1}
$$

Fig. (1). Calculation of the probability of an HIV infection given a positive test result (the positive predictive value, or PPV) based on the same information presented in conditional probabilities (left) and natural frequencies (right). Prevalence $=0.01 \%$, sensitivity $=99.7 \%$, specificity $=99.9996 \%$. Both formulas are versions of Bayes' rule and result in the same PPV of about $96 \%$. probabilities. The two values in the middle level of the tree are simple frequencies and simple probabilities, respectively. Thus, just as conditional probabilities refer to two events, natural frequencies are joint frequencies of two events, such as a positive test and disease [18]. Natural frequencies facilitate computation (and comprehension) because they are not normalized from the second to the third (bottom) level of the tree. In other words, the pairs of natural frequencies at the bottom level add up to the simple frequencies at the second level, which is not the case with conditional probabilities. Hence, calculating the positive predictive value on the basis of natural frequencies is much simpler (compare the two formulas underneath the two trees). Note that natural frequencies should not be confused with relative frequencies, which are normalized and numerically identical to conditional probabilities.

With the help of natural frequencies, physicians, medical students, judges, laypeople, and even 10-year-old children can understand the positive predictive value $[5,11,16,18]$. As the studies with these groups demonstrate, the problem is not simply in people's minds, as has been claimed [20] but is a consequence of the way in which information is represented [21].

Using natural frequencies, a counselor can better understand and also transparently communicate the characteristics of an HIV test result: "Imagine 250,000 heterosexual men like you being tested. We expect that 25 have the virus and will test positive with virtual certainty. Of the other non-infected men, one will also test positive. This is the situation you are in if you test positive: The chance of having the virus is 25 out of 26 , or $96 \%$. "Put like this, the information is easily comprehensible and can be adjusted when prevalence or false-positive rates change. For instance, in a risk group where the prevalence is 1 in $1,000(0.1 \%)$ instead of 1 in $10,000(0.01 \%)$, the positive predictive value is $99.6 \%$ (Fig. 2, left); when the prevalence is 1 in 100,000 $(0.001 \%)$, it is $71.4 \%$ (Fig. 2 , right). Hence, the higher the prevalence, the higher the predictive value, and the lower the prevalence the lower the predictive value.

\section{RESEARCH QUESTIONS}

The general question is whether HIVcounseling for lowrisk clients has improved in Germany since the original study by Gigerenzer et al. [1]. We specifically assessed the

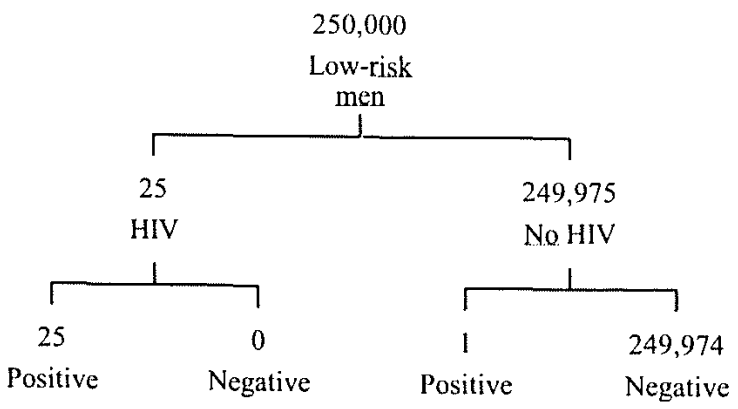




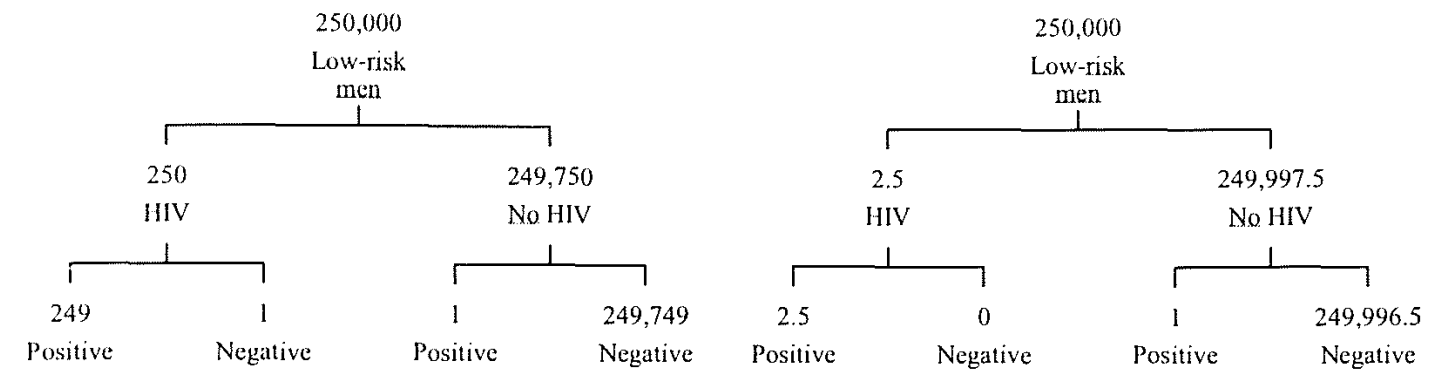

$$
\mathrm{p}(\text { HIV } \mid \text { Test positive })=\frac{249}{249+1} \mathrm{p}(\text { HIV } \mid \text { Test positive })=\frac{2.5}{2.5+1}
$$

Fig. (2). Calculation of the probability of an HIV infection given a positive test result (the positive predictive value, or PPV) with higher $(0.1 \%)$ prevalence (left) or lower $(0.001 \%)$ prevalence (right). In both cases: sensitivity $=99.7 \%$, specificity $=99.9996 \%$.

information counselors provided to the client (see below) on the following aspects:

\section{1) What is the sensitivity of the HIV test? \\ 2) What is the false-positive rate of the HIV test? \\ 3) What is the prevalence of HIV among low-risk men in Germany? \\ 4) What is the positive predictive value?}

The third aspect concerns the prevalence of HIV in our client's risk group. This is important because being at high or low risk affects the positive predictive value, as noted before (see Fig. 2). In addition, we assessed the internal consistency of the information counselors provided, following up the observation by Gigerenzer et al. [1] that information was sometimes contradictory in the course of a counseling session.

\section{METHOD}

\subsection{Sample}

One limitation of the original study was that the sample of 20 centers was a convenience sample. We decided for a more representative approach and randomly drew two public health centers from each of the 16 German federal states $(\mathrm{N}=32)$. The sample included a broad spectrum of city sizes and population densities, ranging from about 10,000 to more than 3,000,000 citizens per city. Of the 32 counselors, 12 were physicians, 17 social workers, two social education workers, and one a nurse. As in the previous study, the sample consists of federal health centers, except in three cases where these centers had outsourced their counseling to the Deutsche AIDS-Hilfe (German Aids Aid, an institution focused on HIV prevention/counseling/testing). Whenever this was the case, the client visited the Deutsche AIDS-Hilfe for pre-test counseling instead. The Deutsche AIDS-Hilfe is also responsible for distributing brochures on HIV counseling to counselors at federal health centers.

\subsection{Data Collection}

In order to collect as realistic data as possible, one of us visited the 32 public health centers in 32 German cities as an "undercover" client. The client presented himself as he was: a low-risk male, 26 years old, heterosexual, currently in a monogamous relationship and with no risky behavior such as intravenous drug abuse. Before these visits, the client was trained to use a structured interview guideline he memorized and covered the four research questions. In the counseling sessions, the client did not use any technical terms such as sensitivity or positive predictive value. For instance, instead of asking about the sensitivity of the test procedure, he first asked a lead question: "How well does the test detect the virus?" Thereafter he asked, "If I have the virus, is it possible that I nevertheless test negative? How often does that occur?"

A pilot study for the original research showed that counselors have the tendency to provide vague and noninformative answers (e.g. "The test is quite reliable; you can trust the test"). Furthermore, asking for clarification more than twice irritated the counselors, who may have experienced the client's insistence on clarification as a violation of social norms of communication. Therefore, the client used the following scheme for clarification questions: If the counselor replied with a quantitative estimate or indicated that he/she could not (or did not want to) provide a quantitative estimate, the client insisted no further and moved on to the next question. If the counselor's reply was qualitative (e.g. "very rcliable"), then the client asked for further clarification and, if necessary, repeated his request for clarification once more. Thus, the client never asked more than two clarification questions after posing the original question per section of the interview. If the counselor did not adequately respond to the client's second clarifying enquiry, the next question was asked. This procedure was also followed when the counselor avoided answering the question. In order to record the data, we trained the client to use a coding system that enabled him to write down relevant information and sentences quickly during/after the counseling sessions. This coding system reported which of the four questions was being addressed, the total number of questions asked (including initial question and clarifying enquiries), and the counselor's answer to each repeated question. The following is an illustration for question 1) on the sensitivity: "1; 2; Very well, the ELISA is a test with high sensitivity; 99.9\%". 


\subsection{Analysis}

Estimates for sensitivity, specificity and positive predictive value provided by the US Preventive Task Force Services report were used to evaluate counselors' accuracy [8]. Because estimates of these could vary, we allowed for a deviation of $+/-2$ percentage points (excluding 100\%) in counselors' estimates. Estimates within this range were classified as "correct", while " $100 \%$ " and corresponding verbal assertions such as "absolutely certain" or "totally certain" were classified as an illusion of certainty. For instance, given that the US Preventive Task Force Services estimates a sensitivity of $99.7 \%$, any response between $97.7 \%$ and $<100 \%$ was classified as correct. For the positive predictive value, which is about $96 \%$ for a low-risk client in Germany, all estimates from $94 \%$ - $98 \%$ were rated as correct. For prevalence, estimates in the range of 6,000 10,000 [22] were rated as correct. When counselors gave inconsistent answers, such as mentioning that false-positive results could occur after having asserted before that the specificity was $100 \%$, we coded the answer in favor of the counselor, that is, not as an illusion of certainty. However, if counselors did provide a correct estimate on sensitivity or specificity but then denied the possibility of falsenegative/false-positive results, their replies were rated as incorrect.

Of the 32 counselors interviewed, two counselors, both social workers, refused to provide answers; one feeling that it was not her duty to answer questions about the reliability of the HIV test and the other openly admitting that she did not know the false-negative or false-positive rates. These two counseling sessions were excluded from the data analysis. Records of all sessions can be found in the supplementary material (see Appendices $A-D$ ).

\section{RESULTS}

\subsection{Sensitivity (False-Negative Results)}

The client asked, "How well does the test detect the virus? If I am infected, is it possible that I nevertheless test negative? If so, how often does that occur?" In their responses, 15 of 30 counselors stated that the test is $100 \%$ certain or absolutely certain (Table 1). For example, one counselor replied: "After the window period, it is $100 \%$ certain. "Seventeen counselors provided quantitative estimates for the sensitivity, seven of which were incorrect or an illusion of certainty. The remaining 13 counselors gave qualitative information to the client. Nine of these 13 counselors denied the possibility of false-negative results. In total, 14 of 30 replies $(53 \%)$ were correct (Table 1$)$.
Among those counselors who mentioned the window period (required diagnostic gap of about twelve weeks between the potential infection and the HIV test), most claimed that the possibility of false-negative results is limited to that period. The window period was said to be only 3 to 4 weeks by one counselor and 10 by another. Six counselors did not inform the client at all about the window period and its diagnostic implication. Altogether, the client had to ask on average 2.7 questions to receive the information he needed.

\subsection{Specificity (False-Positive Results)}

The client asked, "If I don't have the virus, is it possible that I nevertheless test positive? If so, how often does that occur?" Sixteen counselors claimed that false-positive results are not possible because the test procedure includes two tests and/or claimed that the test is absolutely or $100 \%$ certain (Table 1). Two counselors provided correct basic information on the question. For instance, one counselor correctly informed the client about the fact that the proportion of false-positive results to true-positive results (the inverse of the PPV) increases as the prevalence of HIV in the population decreases but could specify neither the false-positive rate nor specificity. Twelve counselors' $(40 \%)$ replies were correct (Table $\mathbf{1}$ ).

Eighteen of 30 counselors used numerical estimates in their replies, of which 13 were not within the range of a correct estimate or were an illusion of certainty. One of those counselors misunderstood the question and (incorrectly) informed the client about the positive predictive value of the HIV test. Of the remaining 12 counselors who provided qualitative information, 5 provided an illusion of certainty. Altogether, the client had to ask 2.5 questions to receive the information he needed.

\subsection{Prevalence}

The client asked, "How many men in Germany who share my characteristics have HIV? "In total, there were 23 numerical replies, out of which 13 were correct. The majority estimated the prevalence around 10,000, while some indicated the prevalence by stating: "three quarters are men who have sex with other men, one quarter heterosexual" or " $73 \%$ homosexuals, $27 \%$ heterosexuals". The remaining 7 replies were qualitative and were classified as incorrect. Some counselors implied that there are no reliable statistics but instead only misleading estimates. Altogether, 13 of 30 $(43 \%)$ replies were correct. The average number of questions asked by the client was 1.6 .

Table 1. Information provided by professional HIV counselors.

\begin{tabular}{|c|c|c|c|}
\hline & Illusion of Certainty (100\%) & Incorrect Estimates Or "Don't Know" & Correct Estimates \\
\hline \hline Sensitivity & 15 (of 30$)$ & 1 & 14 \\
\hline Specificity & 16 (of 30$)$ & 2 & 12 \\
\hline Positive Predictive Value & 18 (of 30$)$ & 11 & 1 \\
\hline
\end{tabular}

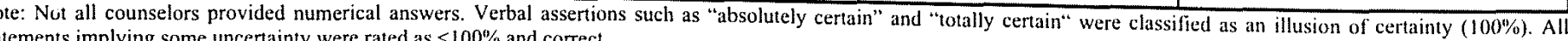
statements implying some uncertainty were rated as $<100 \%$ and correct. 


\subsection{Positive Predictive Value}

The client asked, "If I test positive, how likely is it that I have the virus?" 29 counselors provided incorrect information on the positive predictive value or no information at all. Eighteen of these counselors stated that the client would be HIV-positive with absolute or $100 \%$ certainty if the Western Blot was positive (Table 1). Ten of the 29 counselors provided answers that included statements such as "99\%" or claimed that the positive predictive value is independent of the risk group (low-risk versus high-risk clients). One counselor stated that she could not answer this question. Ultimately, only one out of all the 30 counselors provided a correct estimate. The average number of questions asked by the client was 1.4 .

\subsection{Internal Consistency}

Ten counselors gave internally inconsistent information. For example, when asked about the test's specificity, one counselor (ID 15; see Appendices $A-D$ ) stated that it is " $98 \%$ specific" but then said that no false positives can occur, thereby implying 100\% specificity. When asked about the positive predictive value, he responded, "Yes, the result is then absolutely certain." Another said that the sensitivity is less than $100 \%$ but then said that false negatives (the complement of sensitivity) do not occur. These inconsistent responses document that the counselors do not fully understand the constructs of test statistics such as sensitivity, specificity, or predictive values.

In addition to repeating the analyses performed by Gigerenzer and colleagues, we checked counselors' individual ratio of correct answers out of all answers. Six of 30 counselors did not provide any correct reply to any of the four questions. Eleven counselors provided one correct answer, ten counselors provided two correct answers, and the remaining three provided three correct answers. None were able to correctly answer all of the four questions. Counselors mostly provided correct replies for the client's question about sensitivity and specificity but then failed to give a correct answer to the questions about prevalence and positive predictive value (Table 2 ).

\subsection{Information Formats Used by Counselors}

The majority of counselors (27 of 30 ) used percentages or qualitative information when asked about sensitivity, specificity, and positive predictive value. Only three counselors conveyed information in natural frequencies, one of them correctly. The other two counselors used natural frequencies to bolster their claim that false positives may occur with the ELISA but that these would be sorted out after the Western Blot test was performed. Only when asked about prevalence did the majority of counselors use frequencies instead of percentages and probabilities.

\section{DISCUSSION}

The present study revealed that the quality of counseling has not improved since Gigerenzer et al.'s study in 1998. First, many counselors were not able to provide correct estimates for the sensitivity, specificity, and positive predictive value of the HIV test procedure. Instead, many counselors provided our client with illusions of certainty, namely that 1) false-positive results do not occur and 2) a positive test result implies HIV infection with absolute certainty. The observed inconsistencies in several counselors' replies additionally suggest that many do not understand the exact meaning of sensitivity, specificity, positive predictive value and false-positive/-negative results.

Second, most did not know the prevalence of the HIV infection in low-risk men. Considering the importance of the prevalence of the disease for evaluating the HIV test's performance, it was astonishing that only two of the 30 counselors actually made explicit and detailed inquiries to assess the client's risk group beyond asking whether he was in a monogamous relationship and if he had tested himself for HIV before. The client often had to provide this information unasked in order to give the counselor the necessary background details for judging his risk group. Yet, even though given this information explicitly, $57 \%$ of the counselors were not informed about the prevalence for the client's risk profile and thereby overestimated the prevalence of HIV in his group. One may argue that counselors are mainly exposed to high-risk clients and thus have difficulties adjusting their knowledge to a low-risk client. Nevertheless, a considerable amount of HIV testing for low-risk clients takes place on a regular basis, as well (e.g., HIV testing is part of German pregnancy screenings), and these clients clearly need to be counseled adequately, too. Effective counseling requires counselors who are able to accurately inform whatever risk group is sitting in front of them.

Third, almost nobody used natural frequencies when communicating numbers, although by now a plethora of studies document that experts and laypeople alike comprehend information about test performance much better when it is presented in natural frequencies rather than conditional probabilities [11-15].

Comparing our results to the original results from 1998 , we can see no consistent improvement. Whereas only 5 of 19 $(26 \%)$ counselors denied the possibility of false-negative results in the original study, 15 of $30(50 \%)$ counselors did so in our study. The understanding of the false-positive rate was about the same. When asked about the HIV prevalence among the client's risk group, 16 of $20(80 \%)$ counselors provided incorrect information back then, compared to 17 of $30(57 \%)$ in the present replication. No improvement was found in counselors' replies to the question concerning the positive predictive value of HIV-testing. In the original study, 15 of $18(83 \%)$ counselors provided an incorrect estimate; 28 of 29 (96\%; one counselor could not answer the question) did so in ours. The most important comparison involves the illusion of certainty: In 1998, 55\% of the counselors (10 out of 18 ) stated that a person is definitely infected with HIV when the test result is positive. In the present study this high percentage was even exceeded, with $62 \%$ of the counselors (18 out of 29 ) conveying the illusion of certainty.

\section{CONCLUSION}

Except for information on prevalence, our replication of the study by Gigerenzer et al. found no significant 
Table 2. Correct-incorrect ratio within-subjects.

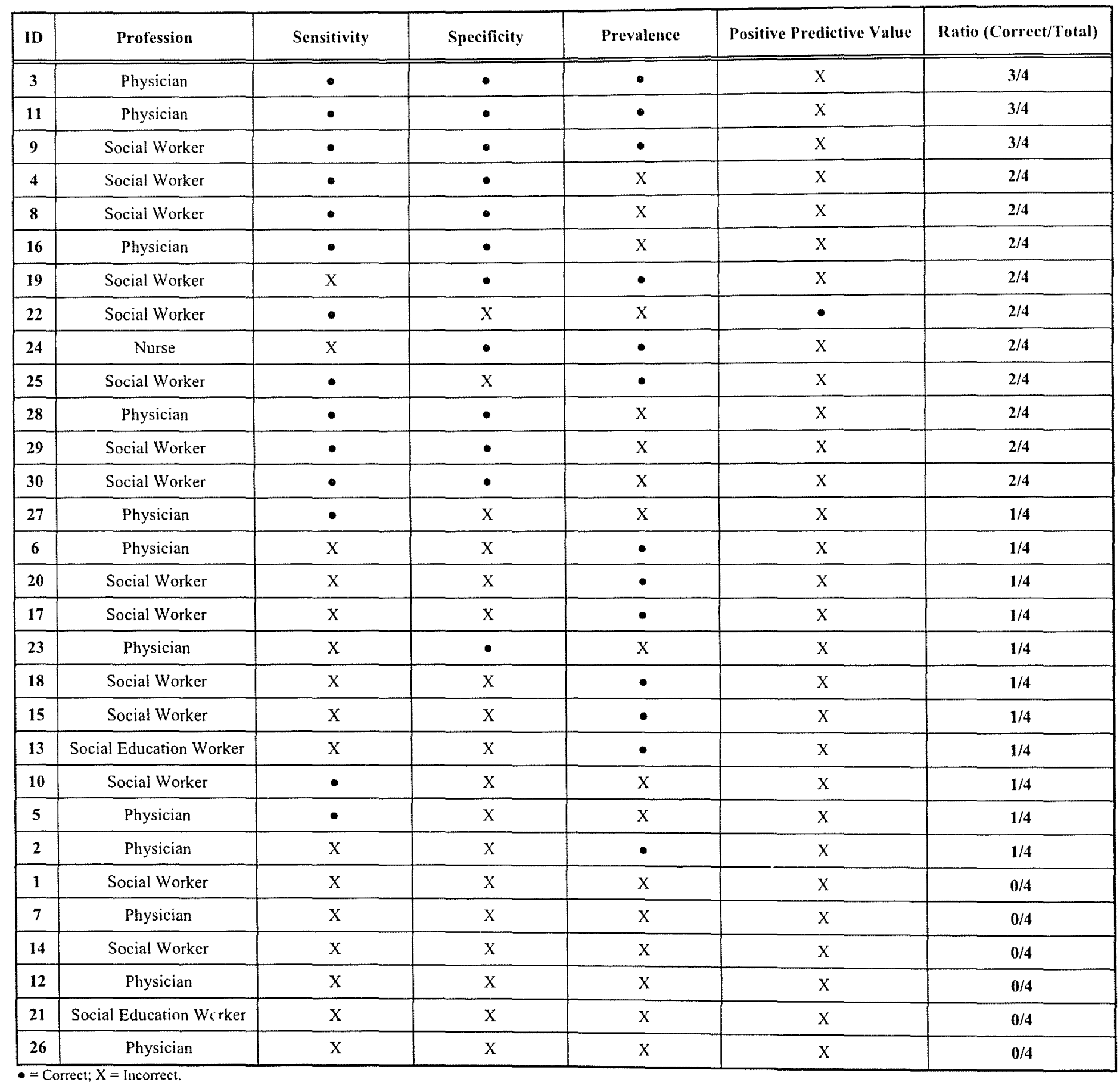

improvement but in fact deterioration in the quality of HIV counseling. Although HIV tests have considerably improved in quality over the last 16 years, counseling has not kept step. Given that after the original study in 1998, all HIV centers in Germany received the results along with a guideline on how to improve HIV counseling, these findings are particularly disheartening. The current key problems are:

1) Use of ineffective statistical formats: Almost all counselors communicated information in terms of percentages and probabilities or just qualitatively, instead of providing natural frequencies that would ease comprehension on both sides.

2) Ignorance of statistics and their implications: Counselors confused the positive predictive value with sensitivity or specificity and did not account for HIV prevalence when talking about HIV test performance. Only one of 30 counselors correctly stated that the positive predictive value increases with an increase of the prevalence of the disease in a group.

3) Illusion of certainty: Most counselors believe that the combination of the ELISA and Western Blot renders HIV test results absolutely certain.

Our replication study should be viewed in the light of some limitations. First, in contrast to the original study, the current study differs in sample size and selection, as well as the actual performance of the HIV test (PPV 1998 $=50 \%$ vs PPV $2014=96 \%$ ). This limits the analysis and interpretation 
of potential differences between these two studies. Second, our data reflect the performance of HIV counseling in Germany and may not be generalizable to HIV counseling in other countries. However, many studies conducted elsewhere on doctors' understanding of test performances show similar difficulties doctors have in working with tests statistics and calculating the positive predictive value so that similar problems are likely to exist in other settings, as well [5, 1315].

Where does the counselors' lack of understanding come from? Part of the problem might be the official information pamphlets. Counselors seem to be equipped with a reference book on HIV counseling distributed by the Deutsche AIDSHilfe (German Aids Aid) or Bundeszentrale Für Gesundheitliche Aufklärung (the Federal Center for Health Education in Germany). During two sessions, counselors took a look at the reference book to find information about the possibility of false-negative results. Based on this information, both counselors concluded that there are no false negatives when the test has been taken twelve weeks after the last risk of infection. An assessment of the brochure made apparent why the counselors arrived at this conclusion: Its content (created by the Deutsche AIDS-Hilfe) consists mainly of qualitative information, which does not enable counselors to retrieve appropriate quantitative estimates.

It should be an ethical imperative that every professional HIV counselor is adequately taught transparent HIV counseling and equipped with brochures that enable to fully understand what a positive test result means. We hope that our study stimulates both better training for HIV counselors and better information in leaflets on HIV testing. Only then can people trust in receiving the transparent and trustworthy information on HIV test results they are seeking.

\section{CONFLICT OF INTEREST}

The authors confirm that this article content has no conflict of interest.

\section{ACKNOWLEDGEMENTS}

Declared none.

\section{APPENDIX A: COUNSELORS' RESPONSES ONSENSITIVITY}

"How well does the test detect the virus? If I am infected, is it possible that I nevertheless test negative? If so, how often does that occur?

\begin{tabular}{|c|c|c|c|}
\hline Numerically Correct & Numerically Incorrect & Qualitatively Correct & Qualitatively Incorrect \\
\hline $\begin{array}{l}\text { "No test is } 100 \% \text { certain, hence, this } \\
\text { may happen."; "This test is } 99.9 \% \\
\text { certain. Therefore, false-negative results } \\
\text { are relatively rare.". }\end{array}$ & "The test is absolutely certain"; " $100 \%$ " & $\begin{array}{l}\text { "Yes, that may occur, especially when } \\
\text { people do not account for the window } \\
\text { period."; "People with many sexual } \\
\text { contacts are prone to that, too. This } \\
\text { happened here once, but one did not } \\
\text { account for the window period back } \\
\text { then."; "Also, this is relatively common } \\
\text { for people who have immune system } \\
\text { deficiencies, e.g. after chemotherapy." }\end{array}$ & $\begin{array}{l}\text { "After } 12 \text { weeks, no. Afterwards, the } \\
\text { test provides a certain result."; "Very } \\
\text { certain, the test is very reliable."? }\end{array}$ \\
\hline $\begin{array}{l}\text { "This happens very rarely, but I have } \\
\text { never experienced it here. After the } \\
\text { diagnostic gap, this is certainly } \\
\text { impossible."; "Absolutely. Well, } 100 \% \\
\text { certainty is never given, but } 99 \% \\
\text { certain." }\end{array}$ & $\begin{array}{l}\text { "After the window period, it is } 100 \% \\
\text { certain." }\end{array}$ & $\begin{array}{l}\text { "The test is very certain. It is relatively } \\
\text { improbable that you are infected if it is } \\
\text { negative."; "Well, as I said, the test is } \\
\text { very certain but theoretically, no test is } \\
100 \% \text { certain." }\end{array}$ & $\begin{array}{l}\text { "I don't know the accurate } \\
\text { numbers."[picks up article]; “After } 12 \\
\text { weeks a false negative is impossible. It } \\
\text { doesn't specify any numbers here } \\
\text { either." } 12\end{array}$ \\
\hline $\begin{array}{l}\text { "Happens, but very unusually. You } \\
\text { have to wait } 3 \text { months before taking the } \\
\text { test, otherwise it is not } 100 \% \\
\text { significant."; "After } 3 \text { months you have } \\
\text { a } 99 \% \text { certain result."; "False negative } \\
\text { results happen, but I don't know how } \\
\text { many. It happens much less than false- } \\
\text { positive results." }{ }_{16}\end{array}$ & $\begin{array}{l}\text { "This is impossible after the window } \\
\text { period."; " } 100 \% \text {." } 17\end{array}$ & $\begin{array}{l}\text { "The test is very sensitive, it reacts to } \\
\text { antibodies immediately. If the detection } \\
\text { test is reactive, you will be informed in } \\
\text { order to perform a confirmatory test."; } \\
\text { "If we don't contact you, then there is } \\
\text { no infection." "30 }\end{array}$ & $\begin{array}{l}\text { "This happens in the rarest cases, with } \\
\text { people who do not produce antibodies."; } \\
\text { "I am not good with numbers, but I can } \\
\text { look it up."(Gets DAH counselors } \\
\text { brochure) "No, it says here that the } \\
\text { result is certain after } 12 \text { weeks, no } \\
\text { exceptions."'is }\end{array}$ \\
\hline $\begin{array}{l}\text { "The test is very good, but nothing can } \\
\text { be excluded for certain."; "It happens } \\
\text { because this test is not } 100 \% \text { certain. } \\
\text { Instead it has } 99 \% \text { certainty."; "I don't } \\
\text { know how often false-negatives } \\
\text { occur." } 25\end{array}$ & $\begin{array}{l}\text { "This is possible if you test yourself } \\
\text { before } 12 \text { weeks or if you have an } \\
\text { immune deficiency."; "Afterwards, it's } \\
\text { absolutely certain."; "100\% certain." } 18\end{array}$ & & $\begin{array}{l}\text { "Not if you keep the window period."; } \\
\text { "Afterwards it is a safe result.; "Very } \\
\text { certain." } 19\end{array}$ \\
\hline
\end{tabular}




\begin{tabular}{|c|c|c|c|}
\hline Numerically Correct & Numerically Incorrect & Qualitatively Correct & Qualitatively Incorrect \\
\hline $\begin{array}{l}\text { "That happens rarely if you account for } \\
\text { the } 12 \text { weeks after having been in a } \\
\text { risky situation."; "The test's sensitivity } \\
\text { is } 99.9 \% \text {, so, it may happen } \\
\text { exceptionally, e.g., with people whose } \\
\text { immune system is malfunctioning, } \\
\text { because it is so sensitive."; "I don't } \\
\text { know the exact frequency." } 28\end{array}$ & $\begin{array}{l}\text { "Well, conditionally no. After the } \\
\text { diagnostic gap, the result will be } \\
\text { significant and a false negative is } \\
\text { impossible."; "100\% certain. Although } \\
\text { you never meet absolute certainty } \\
\text { anywhere." }\end{array}$ & & $\begin{array}{l}\text { "Absolutely impossible after } 12 \\
\text { weeks." }\end{array}$ \\
\hline $\begin{array}{l}\text { "Possible, but rare."; "You have to wait } \\
3 \text { months after you were in a risky } \\
\text { situation, otherwise, the test is not } 100 \% \\
\text { significant."; "After } 3 \text { months it is } 99 \% \\
\text { significant."; "Such results happened } \\
\text { even after } 3 \text { months, but I don"t know } \\
\text { how many. False-negative results occur } \\
\text { generally less than false-positive } \\
\text { results." } 2 .\end{array}$ & $\begin{array}{l}\text { "If taken after } 12 \text { weeks, it isn't } \\
\text { possible."; "The test is very reliable."; } \\
\text { "The test is } 99.9 \% \text { certain." }\end{array}$ & & $\begin{array}{l}\text { "I am not very familiar with these } \\
\text { questions."; "A fter } 12 \text { weeks, no false } \\
\text { negative should occur."; "No it doesn't } \\
\text { occur." } 3\end{array}$ \\
\hline $\begin{array}{l}\text { "The test is significant when taken after } \\
12 \text { weeks."; "This means that the test is } \\
99.9 \% \text { negative if you are negative."'s }\end{array}$ & & & $\begin{array}{l}\text { "If you account for the } 3 \text { months, no."; } \\
\text { "False positives may occur with the } \\
\text { ELISA, but no false negatives." }\end{array}$ \\
\hline $\begin{array}{l}\text { "The test is very certain, if you account } \\
\text { for the } 12 \text { weeks."; "If the test is } \\
\text { negative, then you are negative, too."; } \\
\text { "We are not allowed to say } 100 \% \text {, but } \\
\text { instead we say } 99.9 \% \text {, although the test } \\
\text { is really very certain." }\end{array}$ & & & $\begin{array}{l}\text { "Theoretically, one should stick to the } \\
\text { window period, but antibodies are } \\
\text { already produced after } 3-4 \\
\text { weeks.";"There won't be any false- } \\
\text { negative results after the window } \\
\text { period."; "The test is very sensitive and } \\
\text { false negatives are, if you account for } \\
\text { the window period, impossible.2n }\end{array}$ \\
\hline $\begin{array}{l}\text { "The test is reliable after } 12 \text { weeks since } \\
\text { you have been exposed to infection } \\
\text { risk."; "In medicine, we never say that } \\
\text { something is } 100 \% \text { certain, but this test } \\
\text { is } 99.9 \% \text { certain."; "False-negative } \\
\text { results after the window period have } \\
\text { never happened as far as I know."; } \\
\text { "You undergo double checking." }{ }_{27}\end{array}$ & & & \\
\hline
\end{tabular}

\section{APPENDIX B: COUNSELORS' RESPONSES ON SPECIFICITY}

"If I don't have the virus, is it possible that I nevertheless test positive? If so, how often does that occur?"

\begin{tabular}{|c|c|c|c|}
\hline Numerically Correct & Numerically Incorrect & Qualitatively Correct & Qualitatively Incorrect \\
\hline $\begin{array}{l}\text { "Around } 1-5 \text { false positives in } 1000 \\
\text { tests. But it also depends on the } \\
\text { window period."; "After the } \\
\text { window period you would not } \\
\text { normally get a false-positive } \\
\text { result."; "We also have the } \\
\text { quicktest but that has a lower } \\
\text { sensitivity than the normal test. The } \\
\text { normal has } 99.8 . "\end{array}$ & $\begin{array}{l}\text { "You also have to wait } 12 \text { weeks. } \\
\text { There may be a cross reaction, but } \\
\text { after the diagnostic gap, the result is } \\
100 \% \text { certain."; "There are two tests } \\
\text { anyway"s }\end{array}$ & $\begin{array}{l}\text { "That may happen. For example, } \\
\text { the first test, the ELISA, can be } \\
\text { positive, and the confirmatory test } \\
\text { is negative."; "I cannot tell you how } \\
\text { often that occurs."? }\end{array}$ & $\begin{array}{l}\text { "That never occurred during the } 5 \\
\text { years I have worked here. This } \\
\text { means that false positives are } \\
\text { possible after the search test, but } \\
\text { after the confirmatory that's } \\
\text { impossible."; "The Western-Blot } \\
\text { removes those false positives."; } \\
\text { "After the confirmatory test you can } \\
\text { be absolutely certain that you are } \\
\text { really infected." }\end{array}$ \\
\hline $\begin{array}{l}\text { "The first test is rarely positive } \\
\text { although you are negative. Specific } \\
\text { frequencies do not exist."; "If you } \\
\text { are positive, the Westem Blot is } \\
\text { performed. If this test is still } \\
\text { positive, the same procedure will be } \\
\text { repeated with new blood, so } \\
\text { possible human errors can be } \\
\text { avoided, e.g., in the laboratory. } \\
\text { Afterwards, the test is } 99.9 \% \\
\text { certain."; "Exceptions can always } \\
\text { occur." }\end{array}$ & $\begin{array}{l}\text { "There will be a second test anyway } \\
\text { if you are positive. Afterwards, the } \\
\text { test is certain and significant, } \\
100 \% " \text { " The Elisa would already } \\
\text { be positive after } 4 \text { weeks." }\end{array}$ & $\begin{array}{l}\text { "That happens. Two tests will be } \\
\text { performed if the first is positive, } \\
\text { due to cross reactions. But the test } \\
\text { is generally very significant." } 8\end{array}$ & $\begin{array}{l}\text { "There are two tests that are } \\
\text { absolutely certain."; "If the first is } \\
\text { incorrect - this can happen here - } \\
\text { then the confirmatory test is } \\
\text { performed."; "The confirmatory test } \\
\text { is very sensitive and therefore, the } \\
\text { result afterwards is significant." } 13\end{array}$ \\
\hline
\end{tabular}


(Appendix B) contd.

\begin{tabular}{|c|c|c|c|}
\hline Numerically Correct & Numerically Incorrect & Qualitatively Correct & Qualitatively Incorrect \\
\hline $\begin{array}{l}\text { "Happens, but only after the ELISA } \\
\text { test. If that one is positive, a } \\
\text { confirmatory test follows. } \\
\text { Afterwards, the chance of getting a } \\
\text { false-positive result does almost not } \\
\text { exist, because the test is } 99.9 \% \\
\text { certain."; "I have never seen a false } \\
\text { positive." }\end{array}$ & $\begin{array}{l}\text { "The PPV is } 99 \% \text {, the test is } \\
\text { therefore very certain." } 12 \\
\text { Wrong information, "PPV" }\end{array}$ & $\begin{array}{l}\text { "That happens with the ELISA. After } \\
\text { the confirmatory test that's } \\
\text { impossible because the ELISA has a } \\
\text { higher sensitivity and the } \\
\text { WesternBlot confirms this result."; } \\
\text { "If the WB is positive, a repetition } \\
\text { should be done."; "Human errors that } \\
\text { happen inside the laboratory are the } \\
\text { only possibility."; "As I said, it } \\
\text { happens but the test is very, very, } \\
\text { very certain. We have used this test } \\
\text { for } 30 \text { or } 40 \text { years." }\end{array}$ & $\begin{array}{l}\text { "False positives with the ELISA are } \\
\text { possible but after the second test, the } \\
\text { confirmatory test, not anymore."; } \\
\text { "That is impossible after the test } \\
\text { procedure."; "As I said, I don't know } \\
\text { the numbers." } 22\end{array}$ \\
\hline $\begin{array}{l}\text { "That is relatively impossible. If you } \\
\text { are tested positive, then a second } \\
\text { check is performed."; "99.9\% } \\
\text { certainty because of the double } \\
\text { check." }\end{array}$ & $\begin{array}{l}\text { "The same: after } 12 \text { weeks } 100 \% \\
\text { certainty and therefore false positives } \\
\text { are impossible." } 14\end{array}$ & $\begin{array}{l}\text { "Theoretically, yes."; "I have never } \\
\text { experienced one. There are specific } \\
\text { anomalies, therefore we advise } \\
\text { taking an additional test if the first } \\
\text { one turned out positive." } 8\end{array}$ & $\begin{array}{l}\text { "The same is applicable here: If you } \\
\text { receive a positive result, then you } \\
\text { will have to donate blood again."; } \\
\text { "Afterwards, you can be absolutely } \\
\text { certain." } 25\end{array}$ \\
\hline \multirow[t]{6}{*}{$\begin{array}{l}\text { "False-positive results are possible } \\
\text { after the } 1^{\text {st }} \text { test."; "The test is } 99 \% \\
\text { certain, but I experienced it twice."; } \\
\text { "There are } 4 \text { tests performed in total, } \\
\text { if there is no human error in the } \\
\text { laboratory, then the result is } \\
\text { certain." } 23\end{array}$} & $\begin{array}{l}\text { "False-positive results happen with } \\
\text { the search test, but after that one, the } \\
\text { confirmatory test deletes those."; } \\
\text { "The test is } 98 \% \text { specific, therefore, } \\
\text { the result is relatively reliable."; "No, } \\
\text { false positives do not occur after the } \\
\text { confirmatory test." is }\end{array}$ & $\begin{array}{l}\text { "The ELISA sometimes produces } \\
\text { false-positive results, but I have } \\
\text { never experienced that."; "The Elisa } \\
\text { is very sensitive, the Western Blot, } \\
\text { the second test, very specific."; "If } \\
\text { the result is still positive after the } \\
\text { Western Blot, then you will have to } \\
\text { provide a blood sample again and } \\
\text { this one is tested, too. Afterwards, } \\
\text { the result is very certain."; "There } \\
\text { can always be exceptions. The } \\
\text { smaller the prevalence of an illness } \\
\text { within a group, the more false- } \\
\text { positive results occur. One can say } \\
\text { that for low-risk people, there are as } \\
\text { many false positives as there are true } \\
\text { positives. We have around } 5 \text { positive } \\
\text { results per year, mostly homosexual } \\
\text { men." } 28\end{array}$ & $\begin{array}{l}\text { "The first test is very sensitive, } \\
\text { therefore, a false-positive may occur, } \\
\text { but after the second test the result is } \\
\text { certain."; "False positives don"t } \\
\text { exists, I mean, after the second test } \\
\text { they don't exist."; "But this second } \\
\text { test procedure will be performed } \\
\text { anyway, so you can be absolutely } \\
\text { certain." }\end{array}$ \\
\hline & $\begin{array}{l}\text { "False-positive results rarely occur. I } \\
\text { experienced } 2 \text { cases during the } \\
\text { Mexican flu. But then the } \\
\text { immunoblot test follows and deletes } \\
\text { those. If there are any more doubts } \\
\text { about the result, you can make a } \\
\text { PCR."; "The result is } 100 \% \text { certain } \\
\text { after the immunoblot." } 17\end{array}$ & $\begin{array}{l}\text { "Also possible, depends on the virus } \\
\text { infections."; "When there is a risk of } \\
\text { a false-positive result, then we } \\
\text { generally advice not taking the } \\
\text { test." }\end{array}$ & \\
\hline & $\begin{array}{l}\text { "False-positive results occur with the } \\
\text { ELISA, that one is } 99.9 \% \text { certain. } \\
\text { Therc are around } 1 \text { in } 100 \text { false- } \\
\text { positives, but those will be detected } \\
\text { with the ELISA combi-procedure, } \\
\text { which also tests for a specific virus- } \\
\text { related protein."; "Afterwards, the } \\
\text { test is absolutely certain." } 8\end{array}$ & $\begin{array}{l}\text { "If someone tests positive, a second } \\
\text { test is doneas a double-check. } \\
\text { Afterwards you have a certain } \\
\text { result."; "False-positives results } \\
\text { occur, but usually not after the } \\
\text { Window period." }\end{array}$ & \\
\hline & $\begin{array}{l}\text { "We test around } 300-500 \text { per year } \\
\text { and there are } 3-4 \text { false positives."; } \\
\text { "After the window period those will } \\
\text { be negative, too."; "You can } \\
\text { absolutely rely on the test." } 20\end{array}$ & & \\
\hline & $\begin{array}{l}\text { "A false positive can occur with the } \\
\text { ELISA test sometimes, but there is } \\
\text { always a confirmatory test and } \\
\text { afterwards it is certain."; "After the } \\
\text { search and confirmatory test, the } \\
\text { result is absolutely significant."; } \\
\text { " } 100 \% \text { certain." } 21\end{array}$ & & \\
\hline & $\begin{array}{l}\text { "This happens with cheap tests, but } \\
\text { not after the confirmatory test"; } \\
\text { "After the } 2^{\text {11d }} \text { test it is a } 100 \% \text { certain } \\
\text { result." } 24\end{array}$ & & \\
\hline
\end{tabular}




\begin{tabular}{|c|c|c|c|}
\hline Numerically Correct & Numerically Incorrect & Qualitatively Correct & Qualitatively Incorrect \\
\hline & $\begin{array}{l}\text { "False-positive results happen, but } \\
\text { only after the first blood sample. A } \\
\text { second test is performed if the first } \\
\text { test was positive. Afterwards, errors } \\
\text { are impossible."; "It's a total of } 4 \\
\text { tests with a } 99.9 \% \text { certain test and } \\
\text { false positives are avoided." } 27\end{array}$ & & \\
\hline & $\begin{array}{l}\text { "Two tests are performed, therefore } \\
\text { the result is very certain."; "Also } \\
100 \% . " 1\end{array}$ & & \\
\hline & $\begin{array}{l}\text { "After the window period the result } \\
\text { is also } 100 \% \text { certain."; " } 75 \% \text { false } \\
\text { positives occur when you perform } \\
\text { the test during the window period or } \\
\text { because you belong to a certain } \\
\text { group with very high virus load or } \\
\text { cross reactions."? }\end{array}$ & & \\
\hline
\end{tabular}

\section{APPENDIX C: COUNSELORS' RESPONSES ON PREVALENCE}

"How many men in Germany who share my characteristics have HIV? (Provide further information: heterosexual, no risk behavior such as intravenous drug abuse)"

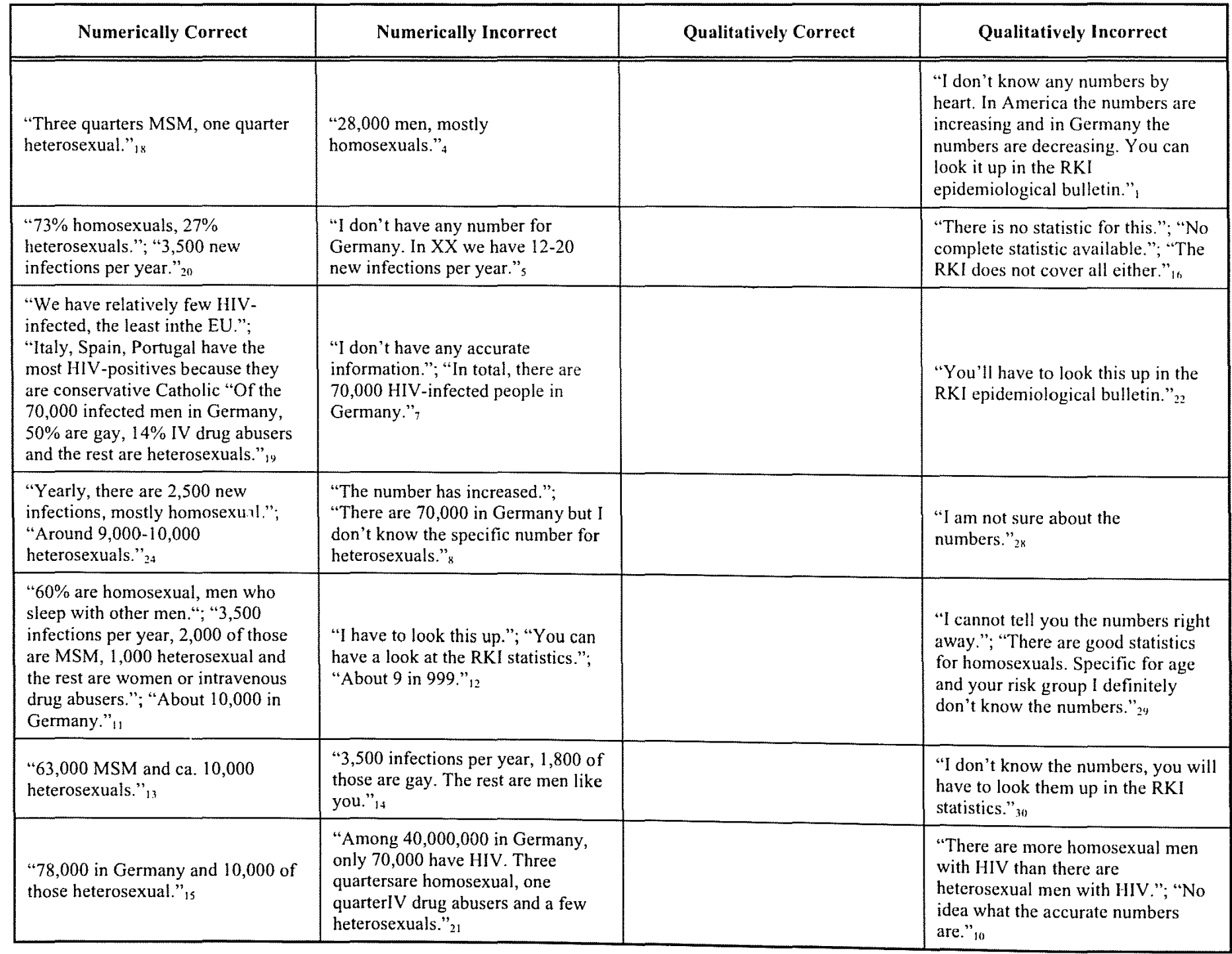


(Appendix C) contd.....

\begin{tabular}{|c|c|c|c|}
\hline Numerically Correct & Numerically Incorrect & Qualitatively Correct & Qualitatively Incorrect \\
\hline $\begin{array}{l}\text { "A small numberof heterosexual } \\
\text { men, around } 10,000, " 17\end{array}$ & $\begin{array}{l}\text { "Ca. } 2,500 \text { new infections per } \\
\text { year."; "Individually, specific to } \\
\text { your risk-group, no idea." } 23\end{array}$ & & \\
\hline $\begin{array}{l}\text { "In total around } 60-70,000 . \text { Men } \\
\text { like you relatively few, ca. } \\
10,000 "{ }_{25}\end{array}$ & $\begin{array}{l}\text { "Around } 78.000 \mathrm{HIV} \text {-infected, } \\
\text { yearly } 3300 \text { new infections." } 26\end{array}$ & & \\
\hline $\begin{array}{l}\text { "There are ca. } 10,000 \text { heterosexual } \\
\text { men who are HIV-positive." }\end{array}$ & $\begin{array}{l}\text { "According to the RKI bulletin: } \\
16,000 "{ }_{27}\end{array}$ & & \\
\hline \multicolumn{4}{|l|}{$\begin{array}{l}\text { "The annual infection rate is } \\
3,000 " ; \text { "There are } 10,000 \\
\text { heterosexuals who are HIV- } \\
\text { infected. Homosexuals who are } \\
\text { infected are by far more common." }\end{array}$} \\
\hline \multicolumn{4}{|l|}{ "About 10,000 heterosexuals." } \\
\hline $\begin{array}{l}\text { "About } 70,000 \text { in Germany, of } \\
\text { whom } 50,000 \text { are homosexual and } \\
10,000 \text { heterosexual." }\end{array}$ & & & \\
\hline
\end{tabular}

\section{APPENDIX D: COUNSELORS' RESPONSES ONPOSITIVE PREDICTIVE VALUE}

"If I test positive, how likely is it that I have the virus?"

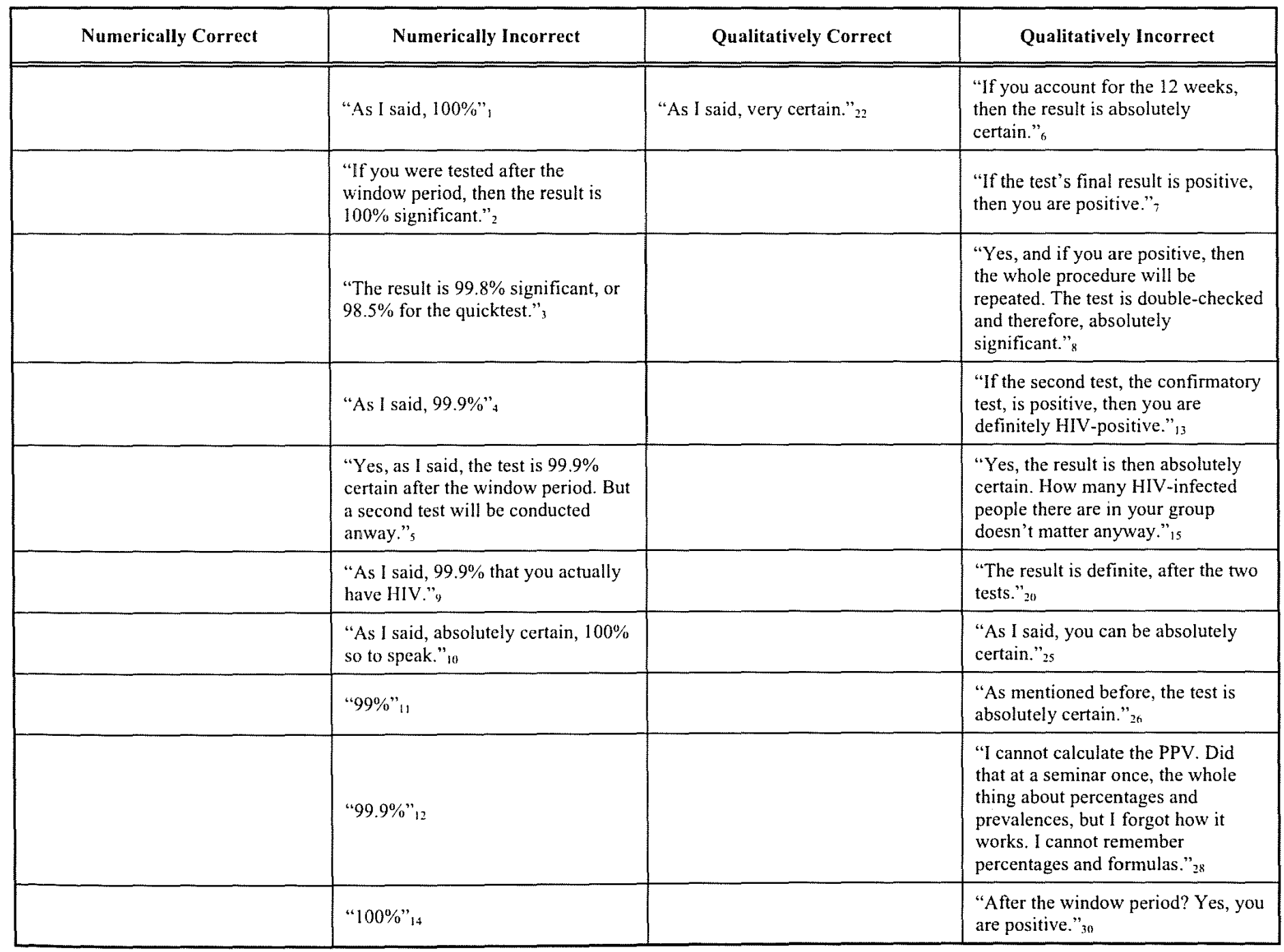


(Appendix D) contd.....

\begin{tabular}{|c|c|c|c|}
\hline Numerically Correct & Numerically Incorrect & Qualitatively Correct & Qualitatively Incorrect \\
\hline & $\begin{array}{l}\text { "After the first test, a second test } \\
\text { follows. After the second test it is } \\
99.9 \% \text {, certain, because it is } \\
\text { impossible to get a false-positive } \\
\text { result twice." in }\end{array}$ & & \\
\hline & "As I said, 100\%"" & & \\
\hline & $" 100 \% " 18$ & & \\
\hline & "99.9\% certainty." $"$ & & \\
\hline & $\begin{array}{l}\text { "False-positives may occur with the } \\
\text { ELISA, but it always follows a } \\
\text { confirmatory test, and then the } \\
\text { result is certain."; "After search and } \\
\text { confimatory test, the result is } \\
\text { absolutely significant. } 100 \% \\
\text { certain."21 }\end{array}$ & & \\
\hline & "After 4 tests, $99.9 \%$ certain." 23 & & \\
\hline & $\begin{array}{l}\text { "If the } 12 \text { weeks were accounted for } \\
\text { and the Western Blot has been } \\
\text { performed: } 100 \% \text {." } 24\end{array}$ & & \\
\hline & $\begin{array}{l}\text { "As I mentioned before, after the } \\
\text { two tests it's } 100 \% \text { that you are } \\
\text { positive." } 27\end{array}$ & & \\
\hline & "With $99.9 \%$ certainty." 29 & & \\
\hline
\end{tabular}

\section{REFERENCES}

[1] Gigerenzer G, Hoffrage U, Ebert A. AIDS counselling for low-risk clients. AIDS Care. 1998;10:197-211.

[2] Gigerenzer G. Calculated risks: How to know when numbers deceive you. New York: Simon \& Schuster; 2002.

[3] World Health Organization. Fact Sheet 1 HIV/AIDS: The Infection [Internet]. 2013 [cited 2013 Oct 18]. Available from: http://www.who.int/hiv/abouthiv/en/fact sheet hiv.htm

[4] Hoffrage U, Gigerenzer G, Krauss S, Martignon L. Representation facilitates reasoning: what natural frequencies are and what they are not. Cognition. 2002;84:343-52.

[5] Gigerenzer G, Gaissmaier W, Kurz-Milcke E, Schwartz LM, Woloshin S. Helping Doctors and Patients Make Sense of Health Statistics. Psychol Sci Public Interes. 2008;8:53-96.

[6] Catalan J, Pugh K. Suicidal behaviour and HIV infection--is there a link? AIDS Care. 1995;7 Suppl 2:S117-S121.

[7] Bhattacharya R, Barton S, Catalan J. When good news is bad news: psychological impact of false positive diagnosis of HIV. AIDS care. 2008. p. 560-4.

[8] Chou R, Huffman LH, Fu R, Smits AK, Korthuis PT. Screening for HIV: A review of the evidence for the U.S. Preventive Services Task Force. Ann Intern Med. 2005;143:55-73.

[9] MacDonald KL, Jackson JB, Bowman RJ, Polesky HF, Rhame FS, Balfour HH, et al. Performance characteristics of serologic tests for human immunodeficiency virus type 1 (HIV-1) antibody among Minnesota blood donors. Public health and clinical implications. Ann Intern Med. 1989;110(8):617-21.

[10] Kleinman S, Busch MP, Hall L, Thomson R, Glynn S, Gallahan D, et al. False-Positive HIV-1 Test Results in a Low-Risk Screening Setting of Volurtary Blood Donation. JAMA. 1998;280(12):10805 .
[11] Hoffrage U, Lindsey S, Hertwig R, Gigerenzer G. Communicating Statistical Information. Science (80- ). 2000;290:2261-2.

[12] Ghosh AK, Ghosh K. Translating evidence-based information into effective risk communication: Current challenges and opportunities. Journal of Laboratory and Clinical Medicine. 2005. p. $171-80$

[13] Eddy DM. Probabilistic reasoning in clinical medicine: Problems and opportunities. In: D. Kahnema, P. Slovic \& A, Tversky, editors. Judgment under uncertainty: Heuristics and biases. Cambridge: Cambridge University Press; 1982. p. 249-67.

[14] Bramwell, R, West, H, \& Salmon P. Health professionals' and service users' interpretation of screening test results: Experimental study. BMJ Br Med J. 2006;333:284-6.

[15] Wegwarth O, Schwartz LM, Woloshin S, Gaissmaier W Gigerenzer G. Do physicians understand cancer screening statistics? A national survey of primary care physicians in the United States. Ann Intern Med. 2012;156:340-9.

[16] Gigerenzer G. HIV screening: helping clinicians make sense of test results to patients. BMJ. 2013;347:f5151.

[17] Hoffrage U, Gigerenzer G. How to improve Bayesian reasoning without instruction: Frequency formats. Psychological Review. 1995. p. 684-704.

[18] Gigerenzer G. On The Art of Risk Communicaiton: What are natural frequencies? BMJ Br Med J. 2011;343.

[19] Zhu L, Gigerenzer G. Children can solve Bayesian problems: The role of representation in mental computation. Cognition. 2006;98:287-308

[20] Kahneman D, Tversky A. Subjective probability: A judgment of representativeness. Cognitive Psychology. 1972. p. 430-54.

[21] Gigerenzer G, Edwards A. Simple tools for understanding risks from innumeracy to insight. BMJ Br Med J. 2003;327:741-4.

[22] Robert-Koch-Institut. Epidemiologisches Bulletin. Epidemiol Bull. $2000 ; 2012(40)$. 